\title{
Roberta Calvo
}

\section{Thermal insulation role and possible exploitation of Posidonia oceanica detritus in the Mediterranean area*}

\begin{abstract}
Calvo, R.: Thermal insulation role and possible exploitation of Posidonia oceanica detritus in the Mediterranean area. — Fl. Medit. 28: 279-285. 2018. — ISSN: 1120-4052 printed, 22404538 online.

The paleoendemic seagrass Posidonia oceanica (L.) Delile represents a key species of the most important and productive ecosystem in subtidal habitats of the Mediterranean Sea. This species is the most common seagrass in Sicily where it forms dense and extensive beds, which are characterized by high coverage and primary production values. The beaching of $P$. oceanica detritus (banquette) can be an environmental, economic and social problem, if it comes into conflict with a number of activities (tourism, bathing establishments, etc.). Even though seagrasses play a fundamental ecological role in limiting coastal erosion and promoting the origin of the coastal dunes, the presence of $P$. oceanica detritus along the coasts can negatively decrease the tourism value of beaches. As a result, according to national and regional laws and guidelines, local authorities are required to remove banquette and to accumulate it in landfills. In this survey, the ancient exploitation and current uses of $P$. oceanica detritus are reported according to literature data. Moreover $P$. oceanica detritus were used to replace soil in an experimental installation located at the University of Palermo. Meanwhile, continuous temperature values measurements by using hobo data logger sensors were carried out. The results confirm the thermal insulation role of this material and highlight potential applications in the field of Soil Bioengineering.
\end{abstract}

Key words: seagrasses, soil bioengineering, circular economy, Sicily.

\section{Introduction}

The world population is expanding incessantly, and economic and demographic growth are leading to the exploitation of the environment and the reduction of natural resources, with potentially important impacts on global climate change (Vörösmarty \& al. 2000). Therefore, more efficient management of resources is necessary, based on the modification of sustainable objectives of environmental policies and strategies and lower consumption of resources. Actions are needed to promote the transition from a linear economy

*Extended and enriched version of the poster presented at the International Symposium "Botany at the intersection of Nature, Culture, Art and Science", Selinunte, 28-30 June 2018. 
model to a circular one, consisting of a continuous positive development cycle that preserves and improves natural capital, optimizing the use of resources (MacArthur 2013).

P. oceanica (L.) Delile is an endemic seagrass found in the Mediterranean Sea, where it forms extensive meadows in the marine infralittoral zone (Duarte 1991). This species is the most common seagrass in Sicily, covering a surface of about 76,000 ha and growing at a depth of 0-50 m (Calvo \& al. 2010). In particular, along the western coasts of Sicily $P$. oceanica meadows form dense and extensive beds, which are characterized by high coverage and primary production values. The seagrass plays a fundamental ecological role in limiting coastal erosion and promoting the establishment of the coastal dune system (Boudouresque \& Meinesz 1982; Simeone \& De Falco 2012; Boudouresque \& al. 2016). As a consequence of phenological process, the beached detritus of $P$. oceanica (banquette) are widely considered a problem by local inhabitants, conflicting with many economic activities such as coastal tourism, bathing, etc. As a result, local authorities are required to remove banquette and dispose them in landfills. In fact, Italian legislation considers these plant biomasses as a special kind of solid waste material to be disposed to landfills, thus resulting in an enormous loss of organic materials, nutrients and useful biomolecules (Saidi \& al. 2009), with additional problems associated with their transport to landfills.

Circular no. 35792/2009, issued by the Sicilian Regional Administration, proposes a management option that consists in the reuse of biomass in landscape reconstruction, as a compost in agriculture or as environmental restoration workin coastal areas (Legislative Decree 75/2010 reforming and revision of the fertiliser guidelines, pursuant to Article 13 of Law no 88 of 7 July 2009).

In this regard, Soil and Water Bioengineering uses plants as living building material in environmental and landscape development works. Such works with low environmental impact promote biodiversity and, in addition, offer a promising strategy for mitigation and adaptation to climate change (Duarte $\&$ al. 2013). Thus, the use of adequate, sustainable, easy to find and low-cost materials is essential for the achievement of these objectives. From the viewpoint of the circular economy, the reuse of $P$. oceanica detritus has a double beneficial effect. It constitutes a solution to the problem of waste disposal and an opportunity for the creation of local and low-cost new products.

Considering the great availability of detritus resulting from the annual cleaning of beaches from the leaves of $P$. oceanica in Sicily, the aim of present work is to test if this detritus could exert a thermal insulation role with potential applications in the field of Soil Bioengineering. For this pourpose an experimental installation located at the University of Palermo were set up, where different treatments consisting of mixtures of $P$. oceanica detritus-soil composed were assembled in modular structures.

\section{State of art of multiple-uses of $P$. oceanica detritus}

The uses of beached $P$. oceanica detritus date back to prehistoric history. In fact, the occurrence of vegetable biomass was detected in the Lazaret's Cave (Nice), where dissected $P$. oceanica detritus were used to build beds (De Lumeley \& al. 1969). The ancient Egyptians made seaball to make shoes (Tackolom \& Drar 1954). Along the coasts of North Africa, in Spain and Balearic Islands (Terrados \& Borum 2004), the beached leaves of $P$. 
oceanica were used for the construction of roofs and bricks for the construction of walls and shafts (Trotter 1915). A rich macrofauna (gastropods, crustaceans, annelids and insects) inhabits the banquettes (Deidun \& al. 2009). Whatever the role of the P. oceanica debris in the diet of the harboured fauna, banquettes are very important as a physical structure that provides detritivorous and predatory species with refuge from environmentally stressful conditions (Colombini \& al. 2009) and top predators such as sea birds (Bartoli \& Prévot 1978; Bartoli \& Holmes 1997). P. oceanica, because of the high content of cellulose, may be suitable for the production of paper (McRoy \& Helfferich 1980). The detritus of $P$. oceanica have found a greater field of application in agriculture as organic substance to increase the fertility of soil (Cocozza \& al. 2009; Parente \& al. 2009; Montesano \& al. 2014; Mininni \& al. 2015; Pirrera \& al. 2017; Calvo 2018). The thermo-absorbent properties of $P$. oceanica leaves, combined with their low density and high porosity (Milchakova 2014), allowed its use as thermal insulator in Greece (Sordina 1951).

Some uses in traditional medicine were confirmed as well as antibacterial and antifungal activity of leaves extracts. Gokce and Haznedaroglu (2008) have conducted a study on diabetic rats, which showed how the oral intake of the extracts of $P$. oceanica, reduces blood glucose and induces blood vessel protection.

Researches on the possible use of $P$. oceanica in cosmetics were introduced by the Company Egadi Natural Cosmetics which defined a protocol of green collection on P.oceanica beached and has obtained an extract with excellent antioxidant properties for a new line of treatment cream.

Finally, several projects have provided for the use of $P$. oceanica detritus. In the whole Mediterranean area there are different experiences of composting, thanks to the high presence of beached detritus of $P$. oceanica along the coasts. In Tunisia, for example, the compost was used as substrate for the cultivation of vegetables and, in particular, tomato (Verlodt \& al. 1983). In Italy, experimental activities of composting and the use of the compost were carried out by serveral authors (Cocozza \& al. 2011; Mininni \& al. 2015; Montesano \& al. 2014). P. oceanica detritus were also recently used in a Soil Bioengineering project to the Municipality of Custonaci (province of Trapani, Sicily) (Pirrera \& al. 2017).

\section{Materials and Methods}

The construction of modular structures was made with organic waste materials, namely detritus of $P$. oceanica and vine pruning (vine shoots). In this regards, vine shoots were assembled in the form of fascines to constitute the basic element used to create a fascinate module, a linear Soil and Water Bioengineering work with anti-erosive, consolidation and stabilization functions, while the detritus of $P$. oceanica were used as a growing medium, to permit it, after planting with native species, an evolution toward a more natural substrate. Finally continuous temperature values measurements using hobo data logger sensorswere carried out whitin different mixtures.

A small prototype of fascinate has been set up in experimental fields at the University of Palermo. ( $38^{\circ} 06^{\prime} 27.73$ “N; $13^{\circ} 20^{\prime} 59.48^{\prime}$ ” E). The work $20 \mathrm{~m}$ long, is structured in 12 
fascines. The fascines were subsequently filled with 30 liters of substrate composed of several mixtures of detritus of $P$. oceanica-soil according to the scheme:

- no. 3 fascine filled with $100 \%$ of $P$. oceanica detritus;

- no. 3 fascine filled with $80 \%$ soil - $20 \%$ of $P$. oceanica detritus;

- no. 3 fascine filled with $100 \%$ soil;

- no. 3 fascine as control.

Temperature values inside the fascines was measured from July to November 2017 by using hobo data logger sensors. The data were recorded continuously every 30 minutes only in a) the external environment, b) inside the $P$. oceanica detritus $(5 \mathrm{~cm}$ depth) contained in fascines and c) in the soil ( $5 \mathrm{~cm}$ depth) next to the installation. On the whole, 18.603 temperature values were acquired.

\section{Results}

During summer, temperature values ranging between $36.6^{\circ} \mathrm{C}$ in $P$. oceanica detritus and $55.1^{\circ} \mathrm{C}$ in the external environment. Instead, in autumn the minimum temperature values measured were $5.6^{\circ} \mathrm{C}$ in the external environment and $9.7^{\circ} \mathrm{C}$ in the detritus of $P$. oceanica. Moreover, maximum and minimum temperature values registered in the soil were $43.2{ }^{\circ} \mathrm{C}$ and $11.9^{\circ} \mathrm{C}$ (Fig. 1).

Lowest average temperature values were recorded in $P$. oceanica detritus inside fascines, both in the summer period $(25.7 \pm 3.6)$ and throughout the measurement period (21.8 \pm 5.2 ) (Table 1).

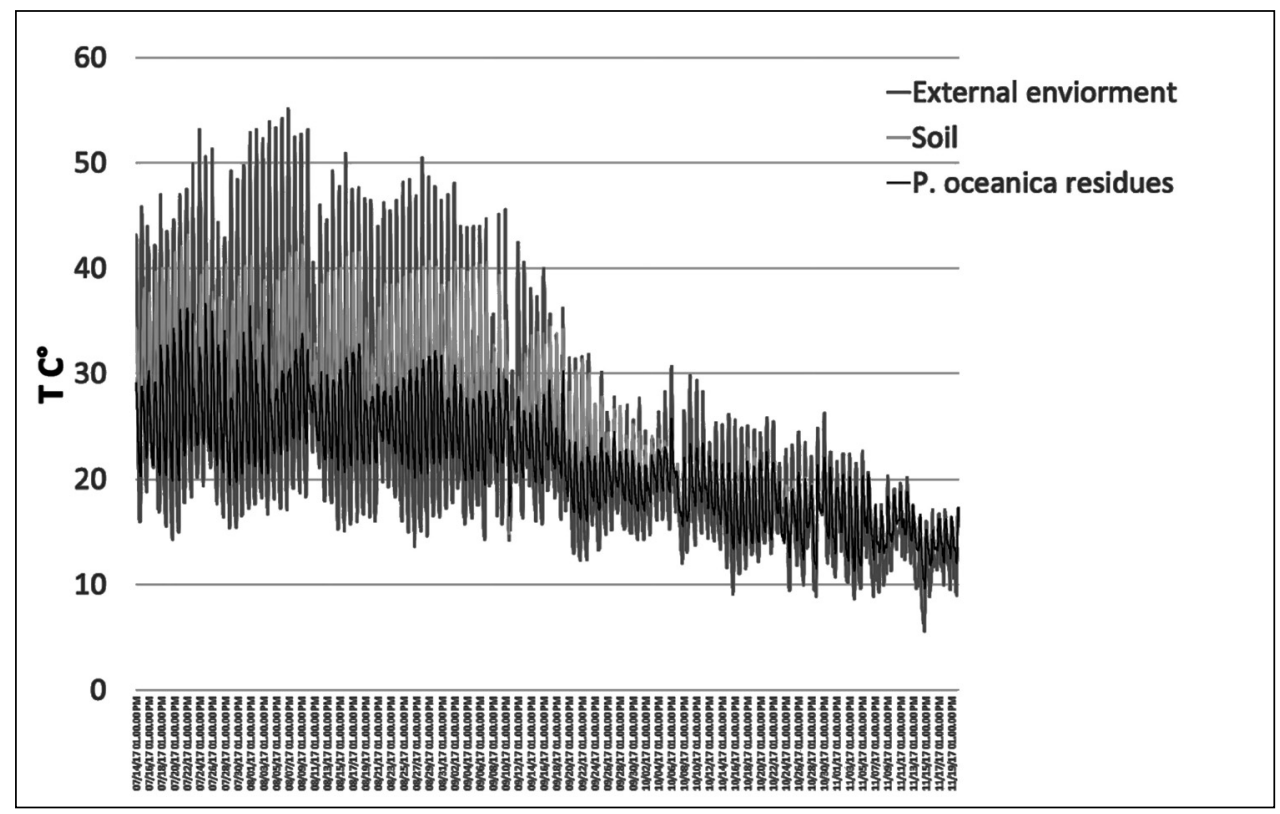

Fig. 1. Temperature values recorded from July to Sempember 2017 during the experiment. 
Table 1. Average temperature values $( \pm \mathrm{SD})$ recorded in the experimental installation.

\begin{tabular}{|c|c|c|c|}
\hline Dates & $\begin{array}{c}\text { External temperature } \\
(\mathbf{m e a n} \pm \mathbf{S D} \text { ) }\end{array}$ & $\begin{array}{c}\text { P. oceanica detritus } \\
(\mathbf{m e a n} \pm \mathbf{S D})\end{array}$ & $\begin{array}{c}\text { Soil } \\
(\mathbf{m e a n} \pm \mathbf{S D})\end{array}$ \\
\hline 14-31 July 2017 & $29.6 \pm 10.2$ & $26.4 \pm 4.2$ & $31.2 \pm 5.1$ \\
\hline 01-31 August 2017 & $29.1 \pm 10.9$ & $26.4 \pm 3.2$ & $30.7 \pm 5.0$ \\
\hline 01-30 September2017 & $23.1 \pm 7.2$ & $25.5 \pm 3.1$ & $25.5 \pm 5.0$ \\
\hline 01-31 October 2017 & $17.8 \pm 4.2$ & $18.3 \pm 2.6$ & $19.0 \pm 2.0$ \\
\hline 01-20November 2017 & $13.7 \pm 3.2$ & $15.2 \pm 2.2$ & $15.8 \pm 1.6$ \\
\hline $\begin{array}{c}\text { 14 July - 21 September2017 } \\
\text { (Summer) }\end{array}$ & $28.0 \pm 10.0$ & $25.7 \pm 3.6$ & $29.8 \pm 5.2$ \\
\hline $\begin{array}{c}\text { 22 September - 20 November 2017 } \\
\text { (Autumn) }\end{array}$ & $16.8 \pm 4.6$ & $17.5 \pm 3.0$ & $18.5 \pm 3.0$ \\
\hline 14 July - 20 November 2017 & $22.7 \pm 9.7$ & $21.8 \pm 5.2$ & $24.5 \pm 7.1$ \\
\hline
\end{tabular}

\section{Discussion and Conclusions}

In the framework of an efficient use of resources and a good waste management, this study underlines the high insulating capacity and the value of $P$. oceanica detritus as a replacement for the plant substrate. In fact, using $P$. oceanica detritus a significant attenuation of maximum and minimum daily temperature values was observed at level of root system, comparing with soil and external environment (Figure 1). Hence, this study suggests that beached of $P$. oceanica detritus, in addition to finding application as thermal insulation in buildings (Sordina 1951; Milchakova 2014), can also be used to promote the rooting and growth of plants that find application for their biotechnical characteristics in the field of Soil Bioengineering (Tuttolomondo \& al. 2017).

Moreover, the use of $P$. oceanica detritus, widely detectable in Sicily and in the Mediterranean basin, represents a valuable example of low cost, sustainable use, energy efficiency and complete respect of the environment. In this context it is also necessary to consider the opportunity to raise public awareness of the importance of seagrass and the beached detritus for the preservation of coastal ecosystems.

\section{References}

Bartoli, P. \& Prévôt, G. 1978: Le cycle biologique de Holorchis pycnoporus M. Stossich, 1901 (Trematoda, Lepocreadiidae). - Z. Parasitenkd, Springer-Verlag. 58(1): 73-90. doi:10.1007/BF00930794

— \& Holmes, J. C. 1997: A transmission study of two sympatric digeneans: spatial constraints and solutions. - J. Helminthol. Soc. Wash. 64(2): 169-175.

Boudouresque, C. F. \& Meinesz, A. 1982: Découverte de l'herbier de Posidonie. - Cah. Parc. Nation Port-Cros, Fr., 4: 1-79.

—, Pergent, G., Pergent-Martini, C., Ruitton, S., Thibaut, T. \& Verlaque, M. 2016: The necromass of the Posidonia oceanica seagrass meadow: fate, role, ecosystem services and vulnerability. - Hydrobiologia, 781(1): 25-42. doi: 10.1007/s10750-015-2333-y

Calvo, S., Tomasello A., Di Maida G., Pirrotta M., Buia M. C., Cinelli F., Cormaci M., Furnari G., Giaccone G., Luzzu F., Mazzola A., Orestano C., Procaccini G., Sarà G., Scannavino A. \& Vizzini S. 2010: Seagrasses along the Sicilian coasts. - Chem. Ecol. 26(1): 249-266. doi: $10.1080 / 02757541003636374$ 
Calvo, R. 2018: Reutilización de residuos de poda de la vid y de Posidonia oceanica en las obras de Bioingeniería del paisaje. 1-95. Ph.D. Thesis. University of Palermo

Cocozza, C., Mininni, C., Zaccone, C., Miano, T., Santamaria, P. \& Parente, A. 2009: Il processo di compostaggio applicato ai residui di posidonia spiaggiata. Il caso dei residui spiaggiati di Posidonia oceanica: da rifiuto a risorsa. - Bari.

—, Parente, A., Zaccone, C., Mininni, C., Santamaria, P. \& Miano, T. 2011: Chemical, physical and spectroscopic characterization of Posidonia oceanica (L.) Del. residues and their possible recycle. - Biomass Bioenergy 35(2): 799-807. doi: 10.1016/j.biombioe.2010.10.033

Colombini, I., Mateo, M. Á., Serrano, O., Fallaci, M., Gagnarli, E., Serrano, L. \& Chelazzi, L. 2009: On the role of Posidonia oceanica beach wrack for macroinvertebrates of a Tyrrhenian sandy shore. - Acta Oecol. 35(1): 32-44.doi:10.1007/s10750-015-2333-y

Deidun, A., Saliba, S., Schembri, P. J. 2009: Considerations on the ecological role of wrack accumulations on sandy beaches in the Maltese Islands and recommendations for their conservation management. - J. Coastal Res. 56: 410- 414.

De Lumeley, H., Pillard, B. \& Pillard, F. 1969: L'habitat et les activités de l'homme du Lazaret. Une cabanne acheuléenne de la grotte du Lazaret (Nice). - Mém. Soc. Préhits France 7: 183-222.

Duarte, C. M. 1991.Seagrass depth limits. - Aquatic Bot. 40(4): 363-377. doi: 10.1016/03043770(91)90081-F

—, Losada, I. J., Hendriks, I. E., Mazarrasa, I., Marbà, N. 2013. The role of coastal plant communities for climate change mitigation and adaptation. - Nat. Clim. Change, 3(11): 961-968. doi: 10.1038/nclimate 1970

Gokce, G., \& Haznedaroglu, M. Z. 2008: Evaluation of antidiabetic, antioxidant and vasoprotective effects of Posidonia oceanica extract. - J. Ethnopharmacol. 115(1): 122-130. doi:10.1016/j.jep.2007.09.016

MacArthur, E. 2013: Towards the circular economy. - Chicago.

McRoy, C. P. \& Helfferich, C. 1980: Applied aspects of seagrasses. Handbook of seagrass biology: an ecosystem perspective. - New York.

Mininni, C., Grassi, F., Traversa, A., Cocozza, C., Parente, A., Miano, T. \& Santamaria, P. 2015: Posidonia oceanica (L.) based compost as substrate for potted basil production. - J. Sci. Food. Agric. 95(10): 2041-2046. doi: 10.1002/jsfa.6917

Milchakova, N. A., Böer, B., Boyko, L. I. \& Mikulich, D. V. 2014: The chemical composition and technological properties of seagrasses a basis for their use. Pp. 313-323 in: Khan, M. A., Böer, B., Öztürk, M., Al Abdessalaam, T. Z., Clüsener-Godt, M., Gul, B. (eds), Sabkha ecosystems, 4. - Berlin. doi: 10.1007/978-94-007-7411-7_22

Montesano, F. F., Parente, A., Grassi, F. \& Santamaria, P., 2014: Posidonia-based compost as a growing medium for the soilless cultivation of tomato. - Acta Horticulturae 1034: 277-282. doi: 10.17660/ActaHortic.2014.1034.34

Parente, A., Mininni C., Montesano F. F., Santamaria P. 2009: L'impiego dei residui di posidonia come substrato di coltivazione. Il caso dei residui spiaggiati diPosidonia oceanica: da rifiuto a risorsa). - Bari.

Pirrera, G., Calvo R., D’Asaro F., Ferrara L. M. \& Lo Nardo C. 2017: Technosoils for the prevention of desertification risk. - World Engineering Forum (WEF 2017) Roma, 26 November- 2 December 2017. - Roma.

Saidi, N., Kouki, S., M’hiri, F., Jedidi, N., Mahrouk, M. \& Hassen, A. 2009: Microbiological parameters and maturity degree during composting of Posidonia oceanica residues mixed with vegetables wastes in semi-arid pedoclimatic conditions. - J. Environ. Sci. (China) 21(10): 14521458. doi: 10.1016/S1001-0742(08)62439-0 
Simeone, S. \& De Falco, G. 2012: Morphology and composition of beach-cast Posidonia oceanica litter on beaches with different exposures. - Geomorphology 151: 224-233. doi: 10.1016/j.geomorph.2012.02.005

Sordina, J. 1951: Marine plants of Greece and their use in agriculture. - Prak. Hell. Hydrobiol. Inst. 5: 73-124.

Tackolom, V. \& Drar M. 1954: Flora of Egypt: Angiospermae, Part Monocotyledones: LiliaceaeMusaceae. - Bull. Fac. Sci., Egypte. 30: 1-648.

Terrados, J. \& Borum, J., 2004: Why are seagrasses important? Goods and services provided by seagrass meadows. - Pp. 8-10 in: Borum, J. Duarte, M. C., Krause-Jensen, D. \& Greve, T. M. (eds), European seagrasses: an introduction to monitoring and management. - Copenhagen.

Trotter, A.1915: Flora economica della Libia: statistica illustrata delle piante coltivate e delle spontanee utili. - Roma.

Tuttolomondo, T., La Bella, S., Leto, C., Gennaro, M., Calvo, R., D’Asaro, F. 2017: Biotechnical characteristics of root systems in erect and prostrate habit Rosmarinus officinalis L. accessions grown in a mediterranean climate. Chemical Engineering Transactions Italian Association of Chemical Engineering - AIDIC. 58: 769-774. doi:10.3303/CET1758129.

Verlodt, H., Ben Abdallah, A. \& Harbaoui, Y. 1983: Possibility of reutilization of a composted substrate of Posidonia oceanica (L.) Del. in a tomato growth bag. - Pp. 439-448 in: Caballero, A. (ed.), International Symposium on Substrates in Horticulture other than Soils. - Barcelona.

Vörösmarty, C. J., Green, P., Salisbury, J. \& Lammers, R. B. 2000: Global Water Resources: Vulnerability from Climate Change and Population Growth. - Science 289(5477): 284288.doi: $10.1126 /$ science. 289.5477 .284

Address of the author:

Roberta Calvo,

Department of Agricultural, Food and Forest Sciences, University of Palermo, Viale delle Scienze, bldg. 5, 90128, Palermo, Italy. E-mail: roberta.calvo@unipa.it 
